УДК 316.42

DOI https://doi.org/10.32837/apfs.v0i28.946

\author{
І. П. Шевель \\ ORCID ID: https://orcid.org/0000-0002-6387-2506 \\ кандидат соиіологічних наук, доцент, \\ доцент кафедри міжнародних відносин \\ Київського національного університету культури і мистецтв
}

\title{
СОЦІАЛЬНЕ НАПРУЖЕННЯ, ЗУМОВЛЕНЕ СОЦІАЛЬНИМИ ЗМІНАМИ ТА СОЦІАЛЬНИМИ РЕАЛІЯМИ, ЯК ФАКТОР СЬОГОДЕННЯ
}

Постановка проблеми. Сьогодні найперспективнішим науковим напрямом $є$ вивчення нестабільного стану в суспільстві, настроїв населення та напруженості, зумовлених соціальними змінами, які останнім часом створюють великі коливання та агресію в державі.

У сучасній науці під соціальною напруженістю розуміється несприйняття будь-якої соціальної зміни в суспільстві, яке набуває особливого стану, змінює свідомість та поведінку людини.

Всі сфери наукового пізнання, які вивчають поняття «соціальна напруженість», вносять свої корективи та створюють нові моделі вивчення в теоретичному та практичному аспектах. Методологічною основою цього дослідження постали наукові роботи сучасних зарубіжних та українських авторів. Слід зазначити, що сучасний стан нестабільності в суспільстві, коливні настрої населення зумовлюють інтерес науковців до такого феномену, як соціальна напруженість. Дослідження соціального напруження серед населення та соціальних настроїв, страхів, суспільних криз є окремим, самостійним феноменом, який займає головне місце в наукових дослідженнях закордонних і вітчизняних науковців.

Останнім часом наше суспільство постійно перебуває в стані соціальної напруженості, невизначеності щодо майбутнього через ситуацію 3 COVID-19, економічний хаос, безробіття, інформаційний тиск, психологічні депресії. Все це викликає соціальну напругу, яка тягне за собою різні конфлікти в суспільстві і може призвести до соціальної кризи в країні.

Аналіз останніх досліджень і публікацій. Аспектичному аналізу соціального напруження серед населення присвячено багато наукових праць різних науковців, зокрема таких західних вчених, як Ч. Спілбергер, Дж. Тейлор, П. Штомка, У Бех, І. Валерстайн, Е. Гіденс, Е. Тофлер та інші. Також вивченням цієї проблеми займались такі вітчизняні науковці, як Є. Суіменко, О. Злобіна, Є. Головаха, В. Судаков, Є. Сірий, В. Танчер, В. Небоженко, А. Горбачик, О. Резнік, І. Шевель, Д. Лікарчук та інші.

Метою статті є аналіз сучасних викликів, наявних у державі, узагальнення підходів до визна- чення поняття «соціальне напруження», характеристика особливостей поширення соціальних настроїв, страхів, протестів.

Виклад основного матеріалу. Соціально-економічні, суспільно-політичні, соціально-психологічні аспекти є ключовими факторами, що зумовлюють виникнення соціальної напруженості серед населення. Ці напруження породжуються нестабільними, неправдивими, невиправдними очікуваннями. Своєю чергою соціальна реакція призводить до деструктивності і соціального конфлікту.

Ми можемо спостерігати під час пандемії, як весь глобалізаційний світ знаходиться в стані дестабілізації. В багатьох країнах світу, і Україна не виняток, відбуваються страйки, деструктивні дії щодо карантинних обмежень. Це все тягне за собою економічну нестабільність, що згодом може призвести до національної небезпеки [9, с. 77].

На думку українського соціолога В. Небоженко, всі соціальні напруженості, які виникають в суспільстві, є звичним явищем. Науковець розглядає соціальну напруженість у двох традиціях: безперервній та універсальній. Перша полягає в тому, щоб привернути увагу до самої соціальної напруженості, показує її зміст, а друга стає детермінантом самої напруженості і показує взаємодію між різними суб'єктами [6, с. 12-14]. Це ми можемо проаналізувати за даними соціологічного дослідження, яке було проведено у 2020 році Харківським інститутом соціальних досліджень. Дослідження виявило ряд факторів, які можуть впливати на ставлення людини до вакцинації від COVID-19. По всій країні спостерігається соціальне напруження стосовно самої вакцини, її походження і країни виробника. Найчастіше напруження i тривога виникають щодо побічних ефектів від вакцинації. Вплинути на бачення людей щодо цього та допомогти населенню прийняти рішення щодо вакцинації можуть тільки наукові факти та роз'яснення фахівців. Це можна зробити передусім за допомогою ЗМІ, оскільки всю інформацію про пандемію, вакцини світу 58,3\% населення дізнається з телебачення. Однак довіряють цій інформації лише $23,9 \%$. 
Останнім часом у різних ток-шоу вакцинують всіх запрошених гостей (за їхньою згодою), щоб популяризувати вакцину і пришвидшити сам процес вакцинації у країні. Соціальні мережі подають $31,8 \%$ інформації, а довіра до неї серед опитаних становить лише 14,3\% . Довіра ж до провідних лікарів становить $18,2 \%$. I це говорить про те, що населення не може прийняти правильне рішення. Країна довго ще буде перебувати в такому стані розпачу [5].

Ситуація, яка склалася в нашій країні, призвела до збільшення соціальної напруженості. Вона набуває характеру силової протидії в різних галузях суспільства [6, с. 89-90]. 3 цього ми можемо побачити, що основною соціальною напруженістю, тривогою, протестами сьогодення є зіткнення економічних інтересів, а не сам факт існування пандемії COVID-19.

За даними соціологічного дослідження Українського інституту соціальних досліджень ім. 0. Яременка, яке було проведено в 2020 році, найважливішими переживаннями є: страх залишитися без роботи $-32 \%$; велика сплата за комунальні послуги, підвищення цін, економічна криза $-27 \%$; прогресивна корупція $-14 \%$; війна на Донбасі - $28 \%$; пандемія та медична реформа $22 \%$. Загалом $95 \%$ опитаних незадоволені своїм рівнем життя, до якого можна віднести всі вищеперераховані показники [4].

На думку українського соціолога Є. Сірого, який у своїй монографії «Дослідження соціальної напруженості в Україні: засадничі аспекти та розробка інструментарію» здійснив спробу розробки системи вимірювально-пізнавальних засобів соціальної напруженості на засадах методології мультирівневого аналізу [8, с. 15], напруженість виникає в певній ситуації. Загострюється і згасає, коли конфлікт стає вичерпним, одна проблема замінюється іншою. Під час пандемії ми можемо бачити саме регіональні проблеми, їх особливості, протести. Кожний регіон впливає на соціальну напруженість і регулює ï, встановлені владні соціальні норми в суспільстві призводять до соціальних змін, які дестабілізують нормальний стан у суспільстві.

Сучасна соціологічна наука вивчає поняття соціальна напруженість як системне явище. На будь-яке явище впливають особливості суспільства, мікроекономічні та макроекономічні чинники. В будь-якому суспільстві, коли виникає якась незрозуміла чи неприйнятна ситуація, поведінка населення набуває стану напруження, ці соціальні напруження відрізняються залежно від специфіки та особливостей кожного регіону. Регіони впливають на напругу, але їхній вплив не однаковий. В Україні соціальна напруга може зростати та генерувати [8, с. 30-31].

В основі соціального конфлікту знаходиться соціальна напруженість, яка виникає через не- задоволеність населення соціальними змінами та умовами соціального середовища $[8$, с. 84]. Якщо пов'яжемо соціальну напруженість з задоволеннями в потребах, то виникають причини для соціальних конфліктів. Це дуже вдало показують Т. Парсонс, Н. Смелзер, Е. Фром, Р. Дарендорф, Е. Гіденс.

Е. Фром показує вплив соціальної напруженості на поведінку людей у ситуації невизначеності [10].

Н. Смелзер зазначає, що колективна поведінка, зумовлена соціальною напруженістю, зазвичай переростає в конфлікт. Зокрема, на думку вченого, напруженість відбувається через недовіру до чиновників, влади [8].

Р. Дарендорф вважає конфлікт природним станом суспільства. На його думку, якщо конфлікти не виникають в суспільстві, то це ненормальне явище. Конфлікти не завжди несуть загрозу, а можуть також нести позитивні соціальні зміни. Соціальні конфлікти Р. Дарендорф поділив на: конфлікт, який залежить від владних відносин; конфлікти, які потрібно врегулювати, тому що вони самі по собі не зникають повністю. Також він зазначає, що загострення конфлікту зумовлює створення різних громадських організацій, особливо в умовах жорсткої влади [3, с. 142-147].

Е. Гідденс вивчав проблему соціальної напруги та протиріч через зв'язок конфліктів. Протиріччя, за Е. Гіденсом, становлять об'єктивні відмінності у системі, суперечності не завжди викликають конфлікт [2].

За Т. Парсонсом, соціальна напруженість - це соціальна система з набором характеристик, яка виникає у разі обмеження соціальної дії з боку нормативного складника системи. Конфлікт супроводжує людину весь процес соціалізації. Конфлікт може перерости в певну напруженість, яка виникає через незадоволеність населення [7, с. 322]. Своєю чергою це сильно відбивається у масовій свідомості, і суспільство надає неправильну оцінку ситуації [9, с. 189].

Як зазначила українська соціологиня О.Г. Злобіна, щодо суспільства, яке постійно перебуває у стані соціальної напруженості і відтворює iii у різних царинах життя, ми можемо говорити про стан «фонової напруженості» кризового соціуму [9, с. 74]. В такому стані дестабілізуються всі соціальні показники в різних сферах, втрачається соціальна збалансованість і виникає системна напруженість високого рівня, переживання про суспільне життя населення, де стан напруги загострюється і набуває форми «боротьби за виживання» $[9$, с. $74-80]$.

Відмінності, які існують в суспільстві між людьми та їхніми майновими статусами, сприймаються по-різному в кризовій ситуації суспільства. Відбувається розподіл на основні і неосновні види 
напруги та суперечностей, які в кінцевому результаті призводять до конфліктів. Відмінності між станами бідних і багатих, керуючих і підлеглих в громадській думці поділилися порівну. За даними моніторингу соціологічних досліджень Інституту соціології НАН України, 47\% відсотків населення вважають, що в Україні наявні гострі конфлікти між бідними та багатими, $43 \%$ вважають, що ці конфлікти є дуже гострими, і тільки 14\% вважають, що конфліктів взагалі немає, і соціальна напруга на цій основі не проявляється [9, с. 80].

Висновки. Підсумовуючи вищесказане, можемо зазначити, що сучасне українське суспільство дійсно постійно перебуває в стані соціальної напруженості. Це прослідковується в сфері зайнятості та загалом в економічній сфері. Сьогодні можна знайти чимало різних методик, наукових праць щодо вивчення поняття «соціальна напруженість» та розуміння природи цього феномену. На нашу думку, на практиці треба постійно проводити інформаційний моніторинг соціальної напруженості, розробляти наукове прогнозування нових джерел напруженості, які виникатимуть в суспільному житті населення в наш сучасний складний час, щоб не наражати населення країни на нові конфлікти, протести, страхи, відчай.

У суспільстві виникає конфлікт інтересів на фоні непримирення щодо розподілу об'єктів інтересу, і ніхто не може запропонувати компроміс, триває супротив та соціальна напруга. Конфлікт може перейти з особистісної сфери на публічно-організаційну, який легко може перерости в соціальний конфлікт [1, с. 83-85].

Негативні тенденції прослідковуються в наш час, оскільки весь глобалізаційний світ перебуває в стані пандемії. IIÏ вагомі наслідки призводять до коливань настроїв серед населення в результаті того, що населення опинилося в умовах «раптової бідності», втративши роботу, доступ до соціальних послуг, втративши соціальні зв'язки, нормальне соціальне життя.

\section{Jimepamypa}

1. Біляк Ю.В. Сучасні концепції дослідження конфліктів інтересів. Еконоліка та держава. № 9. Київ, 2020 C. $83-85$.

2. Гидденс, Э. Социология. Пер. с англ.; науч. ред. Ядов В.А. общ. ред. Л.С. Гурьевой, Л.Н. Посилевича. Москва : Эдиториал, 1999. 703с.

3. Дарендорф Р. Элементы теории социального конфликта. Социологические исследования. Киев, 1994 № 5. С. $142-147$.

4. Дослідження Українського інституту соціальних досліджень ім. О. Яременка. Київ, 2020. URL: http://sau.in.ua/cat-organizations/ukrayinskyjinstytut-soczialnyh-doslidzhen-imeni-oleksandrayaremenka/.

5. Національне українське опитування. URL: https://www.irf.ua/pobichni-efekty-bezpechnist- vartist-pohodzhennya-shho-najbilshe-turbuyeukrayincziv-u-vakczyni-vid-kovid-19-opytuvannya/.

6. Небоженко В.С. Соціальна напруженість і конфлікти в українському суспільстві. Київ : Абрис, 1994. C. $12-14$.

7. Парсонс Т. О структуре социального действия. Москва : Академический Проект, 2000. С. 320-322.

8. Сірий Є.В., Нахабіч М.А. Дослідження соціальної напруженості в Україні: засадничі аспекти та розробка інструментарію. Київ : Глобус, 2018. С. 15-31.

9. Соціальна напруженість у кризовому соціумі: соціальнопсихологічний аналіз / [О.Г. Злобіна, М.О. Шульга, Л.Д. Бевзенко та ін.] ; за наук. ред. О.Г. Злобіної. Київ : Ін-т соціології НАН України, 2019. С. 74-189,

10. Фром Э. Бегство от свободы / Перевод Г.Ф. Швейника. Москва : Аст., 2011. 288 с.

\section{Анотація}

Шевель І. П. Соціальне напруження, зумовлене соціальними змінами та соціальними реаліями, як фактор сьогодення - Стаття.

У статті розглядається феномен соціальної напруженості як фактор сьогодення, розкривається значення впливу соціальних змін на соціальні соціокультурні реалії. Як ми бачимо, реалії сьогодення показують, що постійно виникають конфлікти інтересів, незадоволеність реальністю та подіями, які відбуваються в суспільстві.

Показано, що інтерес до вивчення соціальної напруженості з боку відомих науковців є поширеним явищем. Соціологи, зокрема Є. Головаха, Н. Паніна, О. Злобіна, Є. Сірий, В. Небоженко, М. Міщенко та інші, надають соціологічну інформацію про стан соціальної напруженості, її розвиток, конфлікти в українському суспільстві. 3 цього ми можемо побачити, що ця проблематика підкріпляється різноманітними дослідженнями соціальної напруженості. На цей час проблема набуває нової реальності в суспільстві, нового соціального явища, яке несе в собі наслідковий аспект діï. Тому що пандемія зумовлює вимушені соціальні зміни, до яких населення не готове і не може змиритися 3 дійсністю.

У статті показано дані соціологічного дослідження як вагомого інструменту вивчення динаміки та вимірювання соціальної напруженості в період пандемії COVID-19. Вже пройшов рік, як ми живемо з COVID-19, але люди все одно погано розуміють, яким буде майбутне. Люди звикли розуміти, що будь-які епідемії повинні бути тимчасовими, але досі ми перебуваємо в реальності невідомого, відчуття постійної загрози, незрозумілого майбутнього. «Цінності», які були важливими рік потому, вже не мають значення в умовах економічного спаду, безробіття, небезпеки.

Соціальна напруженість є складним явищем, соціальні зміни зумовлюють нові наслідки: нестабільність соціального середовища, виникнення конфліктів щодо незабезпечення простих базисних потреб для нормального існування населення.

Ключові слова: соціальна напруженість, пандемія, соціальні зміни, соціальні реалії, вакцинація. 


\section{Summary}

Shevel I. P. Social tension caused by social changes and social realities as a nowadays factor. - Article.

The article considers the phenomenon of social tension as a factor of today, reveals the impact of social change on social socio-cultural realities. As we can see, today's realities show that conflicts of interest, dissatisfaction with reality and events in society are constantly arising.

It is shown that the interest in the study of social tension by well-known scientists is a common phenomenon. Sociologists, in particular E. Golovakh, N. Panin, O. Zlobin, E. Siriy, V. Nebozhenko, M. Mishchenko and others, provide sociological information about the state of social tension, its development, conflicts in Ukrainian society. From this we can see that this issue is supported by various studies of social tension. At this time, the problem acquires a new reality in society, a new social phenomenon, which carries a consequential aspect of action. Because the pandemic causes forced so- cial change, for which the population is not ready and cannot accept reality.

The article presents data from a sociological study as an important tool for studying the dynamics and measuring social tensions during the COVID-19 pandemic. It's been a year since we've been living with COVID-19, but people still don't understand what the future will be like. People are used to understanding that any epidemic must be temporary, but we are still in the reality of the unknown, a sense of constant threat, an unclear future. The "values" that were important a year later no longer matter in an economic downturn, unemployment, or danger.

Social tensions are a complex phenomenon, social changes cause new consequences: the instability of the social environment, the emergence of conflicts over the failure to provide simple basic needs for the normal existence of the population.

Key words: social tension, pandemic, social changes, social realities, vaccination. 